Marica Mazurek

\title{
THE INNOVATIVE APPROACH TO RISK MANAGEMENT AS A PART OF DESTINATION COMPETITIVENESS AND REPUTATION
}

The aim of this paper is a critical discussion on application of a framework for tourism disaster management and the response of governments and communities to crises and disasters. Perception of danger and threat might be decisive factors, which could undermine image, reputation, and competiveness of a country. It might have also a decisive influence on the performance of a country from the economic point of view and especially influence on service provisions, for instance infrastructure (transportation), safety and security. The conceptual approach to research is based on analysis and discussion of the applied models of crisis management in tourism. Main purpose of this paper is to overview and compare methodological and conceptual approaches of academics to crises and disasters in published articles dealing with the creation of pro-active risk management models and their application.

Keywords: models of crisis management, competitive advantage, image, reputation, service provision, transportation, cultural differences

\section{Introduction}

Safety and security in tourism are important factors influencing tourists' demand. Countries, depending on tourism, experienced in a future tremendous economic consequences due to external reasons as a result of natural causes or man-made infliction. Vulnerability of tourism destinations is relatively high. Responses of different countries to these events depend on a variety of factors, especially the economic position, the model of governance, preparedness to cope a critical situation, reaction of international community, mass media and business culture. As a consequence of crises and disasters, tourism activities usually decline, the image and competitiveness are undermined. A highly competitive destination does not exist by chance [1-2]. The purpose of this paper is to overview and compare methodological and conceptual approaches of academics dealing with the topic of risk management in their studies, as well as to explore different concepts and approaches to risk management, where each concept requires different methodological approach. As an example of the approach to crises and disasters scenario, a case study of SARS outbreak in Toronto, Canada, has been used.

\section{Literature review}

Main conceptual framework in the studied literature could be divided into specific categories. The first group includes studies dealing with the reasons of events as crises and disasters, the second group discusses the impacts of crises and disasters on economy, tourism performance, services and infrastructure, for instance transportation, community, etc. and the last group is concerned with the attitudes and responds of stakeholders. Each concept requires different methodological approach. The authors in [3-8] discussed the models, which could be used in a case of crises and disasters predominantly in tourism destinations. The second group of authors was dealing with crises management, for example [8].

The predominant approach to research of crises and disasters was embraced by using the inductive research approach (observation, searching for some specific patterns of events and their reasons). The authors; for instance [7], used a broader amount of research and academic literature, which allowed understanding more deeply crises and disasters. The inductive approach was applied in articles $[5-7,9]$.

Some authors tried to develop a generic model suitable not only for tourism destinations, but for different purposes, for instance a country general with its specific requirements of safety, security, service provision (for instance transportation services, etc.). Faulkner applied a deep inductive approach in order to construct generic model of crisis and disasters [3]. Ritchie underlined a necessity of more holistic and strategic approach [9]. Hence, models are more useful for studies of the first group of conceptual approach, e. g. the reasons of crises and disasters and the roles of stakeholders during these events. However, some authors shifted further risk assessment research of crisis management to a different methodological approach by

Marica Mazurek

Faculty of Humanities, University of Zilina, Slovakia

E-mail of corresponding author: marica.mazurekova@fhv.uniza.sk 
questioning particular destination stakeholders, corporate and government representatives, policy makers and planners about their preparedness to deal with crises and disasters [6]. As the authors stated, "the purpose was to produce insight rather to test theory, the study was inductive in nature and used a qualitative, interpretative approach" [10]. Their research revealed, through interviewing of experts on corporate and government security, safety, tourism policy and planning, some controversial aspects of former research approaches based on compiling of theoretical frameworks without testing the attitudes of stakeholders. A research underlined necessity of the co-operative approach of all the stakeholders, compatible jurisdiction, allocation of financial resources, etc. Thus, the pragmatic approach to the studied topic revealed important gaps between the managerial theoretical approach and practice. Similar experience was perceived after the implication of pro-active generic models in real settings, where interviews with individual tourism operators and DMOs (Destination Marketing Organizations) representatives were used, which allowed deeper insight into the topic of crises and disasters. In that case a complicated character of tourism research is visible, where knowledge in tourism could be approached from two angles. One is delineated by the multidisciplinary character of tourism studies rather than a single discipline. It causes blending of academic disciplines by implication of the statement of "knowing that" (e.g. what we know that we know) together with specific disciplines, which are close to tourism studies (sociology, psychology, geography, anthropology) [11]. However, in the case of managerial decisions in tourism, the second type of knowledge, e.g. "procedural knowledge ("knowing how"), based on professional practice of tourism management and marketing, has to be implemented.

As a consequence, if some researchers tried to understand impacts of tourism stakeholders and business environment (the second concept) to crises and disasters, or attitudes of community and stakeholders (the third concept), this approach required totally different paradigmatic approach. For example, for studies of attitudes and responds of stakeholders in the studied articles, researchers used such methods as phenomenology and interpretive approach, which are based on understanding of real experiences of participants. Moreover, in some case studies, peculiarities in the implementation of generic models into specific cultural or business environments, were described.

Some researchers applied the post-positivist approach and studied the impact of the two variables, frequency and severity of terrorist events, on decline of demand. Quantitative methods, based on survey research, have been applied in research on changing attitudes of visitors to the destination after crisis and disasters.

A case study, used in Katherine flooding research, was based on the implication of Faulkner's generic pro-active risk management model. Prideaux, Laws and Faulkner discussed the application of forecasting methods by blending the qualitative and quantitative methods [12].
The forecasting methods could be useful to predict some developments, but not the consequences, and the authors stated. That "understanding the impact that unexpected disruption may have on tourism flows is important for forecasters, planners, investors and operators" [12].

The studied conceptual and methodological approaches to crises and disasters in the academic literature enabled to understand deeper the impediments of research of crises and disasters. The following research on the content of literature dealing with crisis and disasters managerial approaches required specific methodology and methods.

\section{$3 \quad$ Methodology}

The method of content analysis of articles in existing journals and the secondary sources on internet and in publications was used in research. The main focus of the article was on application of model of crisis and disasters and the specific case studies from inflicted countries. This research has a strong conceptual character. A method of the case study from Canada has been used in this study. The studied materials have been collected during the study stay in Canada at the University of Waterloo as well as in further research. This case study is based on the secondary research of the existing literature. Additional literature, which was used for the content analysis, was selected upon the required topic studied in this research. Tourism studies research is rather complicated where an influence of different epistemologies and disciplines might be visible. For this reason, research was dealing with a question how different authors approached a topic of studies from the methodological point of view.

Additionally, the strategic approaches to crisis and disasters have been studied and compared in different countries and cultures. This information was based on the studied secondary sources.

The articles were selected from different academic journals (Table 1 contains a list of studied academic journals containing a sample of 32 academic papers and 5 books). The content analysis was thoroughly focused on the methodological approaches of the authors to the studied topic.

\section{Results}

Drawing from the insight in academic literature, on crises and disasters, published in journals since 1999 until now, one can see that majority of published articles were trying to develop deeper understanding based on previous academic work in this field. Scholars discussed especially the applicability of models, complications with implementation, managerial tasks and application of models in culturally diverse environment. The marketing recovery strategy revealed a crucial role of mass media.

Some articles discussed the applicability of models into real situations. For example, in 2001 a generic pro- 
Table 1 Content Analysis of the articles and books

\begin{tabular}{|c|c|}
\hline Journal of Vacation Marketing & Tourism Management \\
\hline 1. Litvin and Alderson (2003) [13] & 20. Faulkner and Vikulov (2001) [7] \\
\hline 2. Frisby (2011) [14] & 21. Paraskevas and Arendell (2007) [6] \\
\hline 3. Fall (2004) [15] & 22. Ritchie, (2004) [9] \\
\hline 4. Yeoman, Lennon and Black [16] & 23. Faulkner (2001) [3] \\
\hline 5. de Sausmerez (2005) [17] & 24. Quintal, Lee and Soutar (2010) [30] \\
\hline 6. Barton (1994) [18] & 25. Prideaux, Laws, and Faulkner (2003) [12] \\
\hline 7. Durocher (1994) [19] & 26. Pauchant and Mittroff (1992) [31] \\
\hline \multicolumn{2}{|l|}{ 8. Beirman $(2002,[20]$} \\
\hline Journal of Travel Research & Crisis Management in Tourism \\
\hline \multicolumn{2}{|l|}{ 9. Henderson (1999) [21] } \\
\hline \multicolumn{2}{|l|}{ 10. Milo and Yoder (1991) [22] } \\
\hline \multicolumn{2}{|l|}{ 11. Pizam and Fleischer (2002) [23] } \\
\hline 12. Drabek (1995) [24] & 27. Campiranon and Scott (2007) [32] \\
\hline \multicolumn{2}{|l|}{ 13. Mansfeld (1999) [25] } \\
\hline \multicolumn{2}{|c|}{ 14. Sonmez, Apostolopoulos and Tarlow (1999) [8] } \\
\hline \multicolumn{2}{|l|}{ 15. Goodrich (2005) [26] } \\
\hline \multicolumn{2}{|l|}{ 16. Pizam (1999) [27] } \\
\hline Annals of Tourism Research & Disaster Prevention and Management \\
\hline (2005) [28] & 28. Heath (1998) [4] \\
\hline Current Issues in Tourism & e-Review of Tourism Research (eRTR) \\
\hline 18. Miller and Ritchie (2003) [5] & 29. Tarlow (2004) [33] \\
\hline 19. Var, Brayley and Korsay (1989) [29] & 30. Tarlow (2005) [34] \\
\hline \multicolumn{2}{|l|}{ Books } \\
\hline \multicolumn{2}{|l|}{ 31. Crouch and Ritchie (2003), [2] } \\
\hline \multicolumn{2}{|l|}{ 32. Hall (1994) [35] } \\
\hline \multicolumn{2}{|l|}{ 33. Hofstede (2001) [36] } \\
\hline \multicolumn{2}{|l|}{ 34. Mansfeld and Pizam (2006) [37] } \\
\hline 35. Wall (2006) [38] & \\
\hline
\end{tabular}

active risk management model was used in the Foot and Mouth Disease outbreak in Great Britain and in 1998 during the flooding in Australia (Katherine floods). The academic discussions tried to divide crises and disasters into specific groups based on infliction. The goal was to generate a set of rules or managerial approaches during the crises and disasters in a form of a holistic model of disaster management strategy. As a result, Faulkner's pro-active generic risk management model or Ritchie's holistic model were generated, but the applicability of created models was disputable.

Academics predominantly expressed consensus in a matter of division of crises and disasters into two groups, but could not find a boundary between them. For example, in Figure 1 a case of Lockerbie caused by human infliction, was by Faulkner named as a disaster, but the classification of this event was a terrorist attack in the air industry [3]. This table was created before 2001 and the general knowledge on crises and disasters did not experience such events as $9 / 11$ or Bali terrorist attacks, terrorist attack in Egypt, Tsunami in Asia, SARS outbreak in Asia and Toronto,
Canada. The emerging events later, even more pointed out at the necessity to deal with this topic generally, not only in tourism context, because a tourism destination is also a place with local people and local industry.

The authors dealing with crises and disasters criticized problems of "inept management structures and practices or a failure to adapt to change" [3, 9]. Ritchie added that "a crisis implies the need for change to prevent the situation occurring again, while a disaster requires responses to limit the impacts" [9]. As the author explains, important is the ability to act or change the situation, not only to define a type of events based on infliction. Some cases could bear features of both events, as for example Foot and Mouth Disease outbreak (health care negligence with a serious ripple effect on agriculture, tourism).

The authors had a problem with a definition of crisis and disasters, for example Selbst defined crisis as "any action or failure to act that interferes with an organization's ongoing functions .... that has a detrimental personal effect as perceived by the majority of its employees, clients and constituents" [39]. The problem with this definition is that 

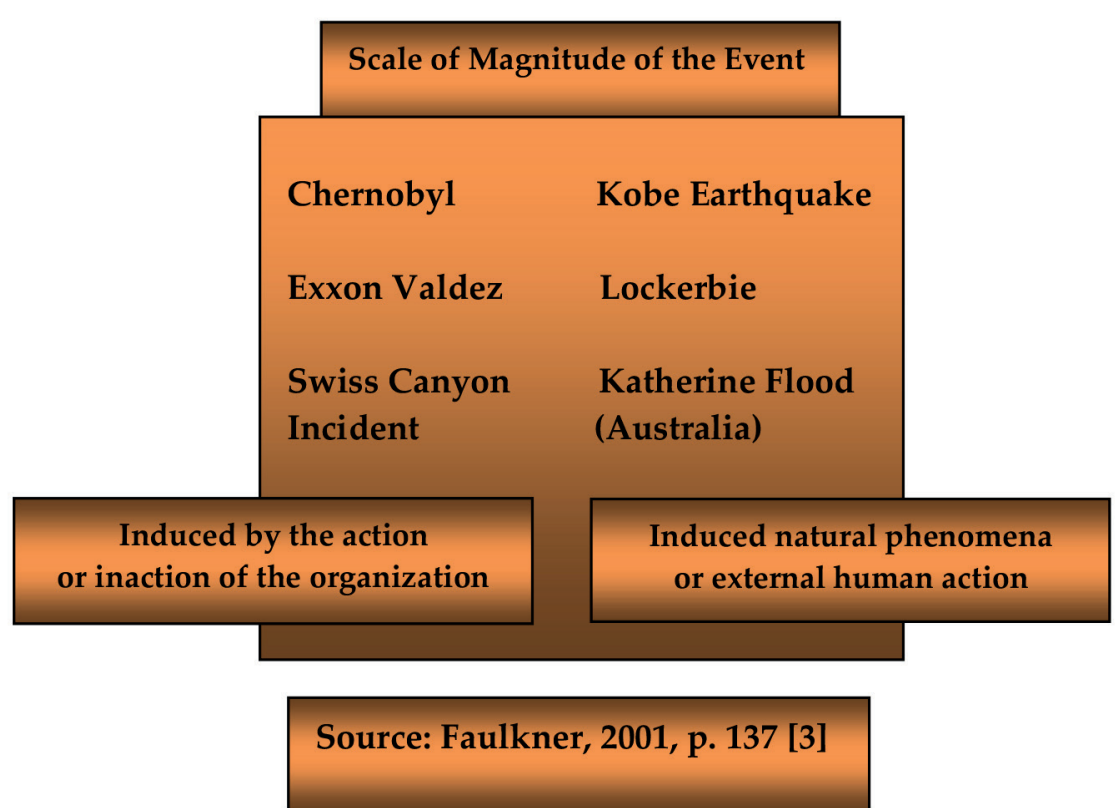

Figure 1 Crises and disasters

it only defines crises, and as Faulkner stated, "Selbst's definition of crisis seems to exclude situations where the survival of an organization of community is placed in jeopardy because of events over which those involved have little control [10]."

During the development of different types of crises and disasters, evident was a shift from crisis management models [38] to pro-active risk management models [3] or holistic models [9, 40-41], which was perceived as "an established management decision-making aid......for proactive decision making that continuously assesses potential risks, prioritizes the risks and implements strategies to cope with those risks" [42]. Creation of a generic model by Faulkner underlined a necessity for the pro-active approach to tourism disaster management, continuous assessment of risks, development of scenarios in the pre-event stage and use of the forecasting techniques. His attempt to generate this type of model for tourism destinations is contributory and positive because all the former crises management models were developed for business environment, Pauchant's and Mitroff's model [31], Ritchie's model [28], Faulkner and Vikulov's models [7] etc. Faulkner's generic pro-active risk management model was used in the 2001 Foot and Mouth Outbreak in the United Kingdom, which was a case of a crisis in agriculture; however, the ripple effect on tourism industry in the United Kingdom was evident.

More discussion is needed on perception of disaster management framework of models (re-active models) and pro-active risk management models as has been stated by some academics in academic journals. The first academic, who identified these two approaches to model creation in crisis and disasters, was Heath, who mentioned the traditional crisis management approach and the risk management approach [4]. Miller and Ritchie added that "the traditional crisis management approach involves no initial (pre-crisis) planning or management (Figure 2) ... and the role of risk management approach "is to respond to the crisis and manage the impacts effectively and efficiently (Figure 3) [5].

Application of the same model in different type of disaster or crises and in different countries, cultures, might be a real constraint. Almost ten years later, Campiranon and Scott (2007) revealed "that national culture has a significant impact on crisis management" [32]. To support this idea, Heath noted that "responses of different governmental representatives to crises and disasters are based on their cultural rules" [4]. Specifically, he mentioned that "after the 1995 Kobe earthquake Japanese cultural orientation towards bottom-up consensus in decision-making also affected the timeliness of the response." Eastern cultures do not react the same way as western cultures and their hierarchical approach to the decision-making process could be a strong argument that generic would not be implemented in the same way as it would be in western societies. Some form of criticism also lies in adoption of similar management methods to different management environments. For example, some authors compared the differences between reaction of American and Chinese managers while dealing with uncertain situation: "having a high uncertainty avoidance culture, Chinese managers normally lack an adventurous spirit and the sense of risk. On the other hand, low uncertainty avoidance American managers are more likely to accept risk" [43]. These examples only confirm what the other authors discussed as being in impertinent situation for implementation of models in different environments. Thus, academics as Faulkner mentioned this possibility by stating that "different internal cultures and modus operandi barriers to communication and co-operation between organizations" [3].

In addition, Campiranon and Scott discussed the influence of socio-cultural concepts on the successful 


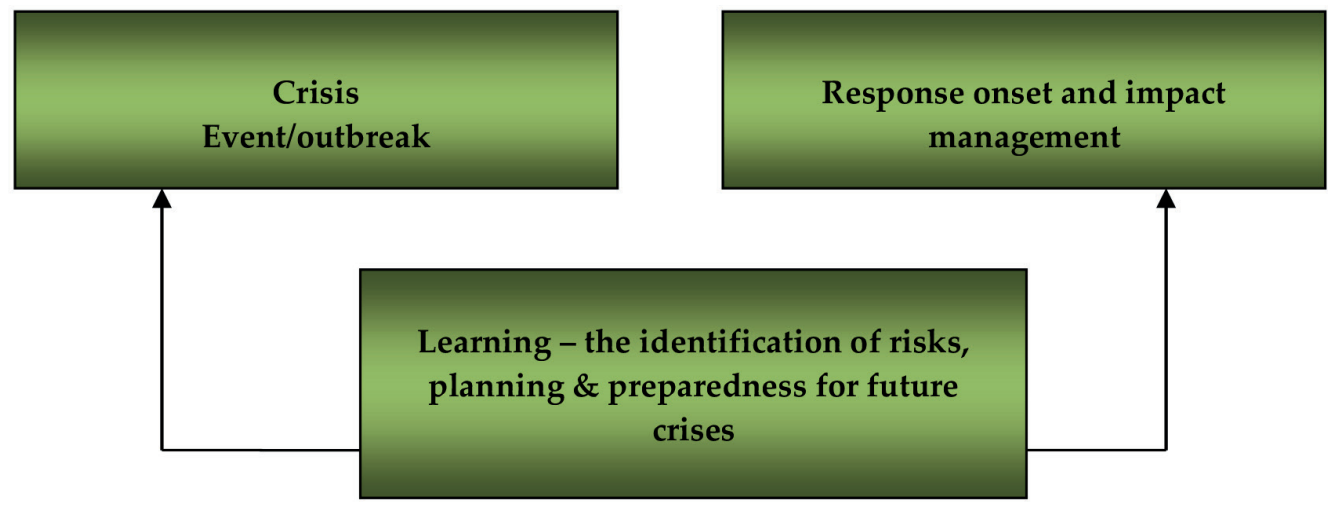

Source: Heath (1998) [4]; Miller, Ritchie (2003) [5]

Figure 2 A traditional approach to a crisis

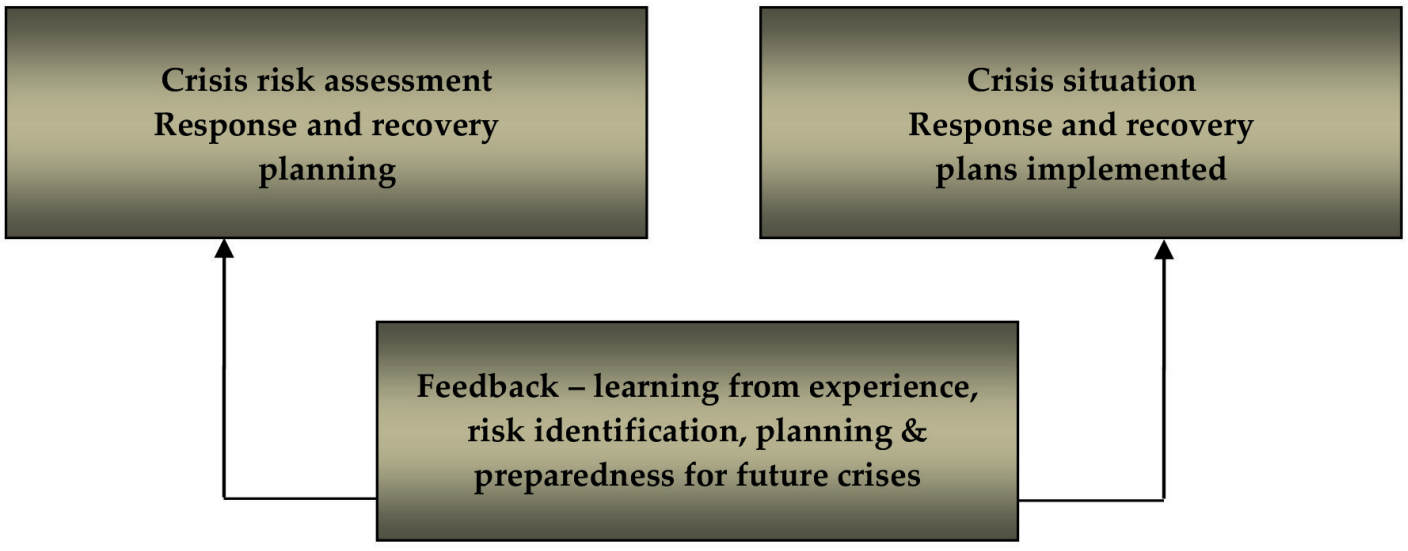

Source: Heath (1998) [4]; Miller, Ritchie (2003) [5]

Figure 3 A risk management approach to a crisis

implementation of crises management strategies in organizations or different entities [32]. Johnson and Peppas mentioned that "crisis intensity varies from country to country and culture to culture, which means that it is very important that crisis response plans are developed for a specific location" [44]. Okumus and Karamustafa stated that the success of each pro-active model depends on national culture and in some cultures "despite experiencing so many severe disasters, both tourism organizations and government officials still ignore the need to employ a proactive approach to managing crises" [29]. This is perhaps a partial reflection of the national culture in Turkey's business environment. In Turkish culture reliance on public sector interference is not identical as for example in western cultures. The existence of different approaches of governments and cultures to crises and disasters is evident and this might also influence particular stages of recovery process described in generic models.

The above stated authors (Faulkner, Ritchie, Paraskevas and Arrendell) mentioned the role of mass media during the crises and disasters. Media could become the so called double-edge sword of media involvement in crises as being a helpful factor in dissemination of information, but also a hindering factor that creates more chaos and ruins image of a destination. Frisby studied the impact of media and public relations after the outbreak of the Foot and Mouth disease in Great Britain in 2001 and 9/11 in New York in 2001 and studied the role of the BTA (British Tourist Authority), dealing with marketing and promotion of Great Britain overseas and creation of an image of Great Britain as a destination [14]. Image is crucial for destinations' competitiveness because creation of an image in the marketing concepts is a long-period process, and visitors tend to respond quickly and avoid visit problematic destinations. As Frisby commented "BTA created a public relations strategy and program to fulfill its objectives in re-establishing tourism from overseas as rapidly as possible" [14]. Similarly, Fall discussed about the role of mass media and public relations after crisis and disasters occur and stated that "crisis has the potential to impact negatively on an organization's image" [15]. Faulkner commented that "media outlets can help by dissemination warnings...however they can also hinder emergency operations by spreading false information" [3]. The recovery stage of the generic model includes the media communication strategy and the role of media and recovery 
marketing strategies is crucial for a success of a recovery. Faulkner added that "a media communication strategy... (is) essential in order to ensure that misleading and contradicting information". However, in some of discussed articles examples opposing the description of the media communication strategy were used and criticized their attempts to exaggerate. In some cases, the media reports have a potential to have a devastating impact on disasteraffected destinations. This scenario was confirmed for instance in the SARS outbreak in Toronto, Canada in 2003.

\section{Case study in Canada}

The outbreak of SARS (Severe Acute Respiratory Syndrome) did not have an extreme impact on mortality of people because only 45 people died, but an immediate effect was evident in tourism industry. Over 1/3 of 95000 employees in tourism were laid off (based on Smith Travel Research) after the SARS outbreak and total decrease of tourism revenue due to SARS was 500 million in Toronto, Ontario in the following months. From April to June 2004, the number of international visitors declined $14 \%$, their spending declined $13 \%$ and the travel deficit in the income from international tourism was over 1.1 billion $\mathrm{CAD}$ together with the decrease of employment in tourism by $2.4 \%$, KPMG, PKF Consulting [38]. Inflicted were also businesses in Toronto, not only in tourism, but generally. For instance, restaurants experienced 20-30\% decline, and other services (education, health and social services, retail, transportation) were also hit due to SARS outbreak. Additionally, at least five major conventions and events were cancelled (over 20000 attendees, cancellation of bus tours, music concerts), etc. Ontario is one of major economic powers besides Alberta, which contributes by $40 \%$ to Canada's GDP and Toronto is a creator of $20 \%$ of GDP ( 1 billion CAD off in 2003). Based on the secondary research of Wall [38], KPMG, PKF Consulting sources, the Federal government invested to public sector additionally 650 million $\mathrm{CAD}$ on tax relief of inflicted business, discounts of prices of flight tickets, PR events, 25 million CAD marketing campaign due to the SARS outbreak. The businesses in Toronto were given 5 month tourism tax holiday and 10 million CAD was spent on business recovery strategy. The Provincial government added 118 million CAD for SARS Recovery package (66.8 $\mathrm{CAD}$ - global confidence in Toronto, 9 million CAD on event marketing, 8 million CAD on events. The total revenue loss in Toronto in April 2003 compared to April 2002 was 97 mil. CAD, compared to other Canadian cities as Montreal (17.1 mil. CAD), Ottawa (7.1 mil. CAD), Calgary (6.2 mil. CAD) or Vancouver (39.1 mil. CAD). The impacts of SARS on hotel market in the first quarter of 2003 compared to the same period of 2002 revealed \%-age decrease in all provinces of Canada, but major decrease was indicated in Ontario (- 18.5\%) compared to the total decrease (-11.0 $\%)$. The same source of information (Conference Board of Canada) discussed the impact of SARS crises on economic activity at Pearson International Airport in Toronto, where the loss in revenues in the $2^{\text {nd }}$ quarter of 2003 were 403,7 mil. CAD. These outcomes testify on the importance of the phase of recovery and especially the creation of image and co-operation with media in the recovery phase.

Except the investment incentives in the process or recovery, Faulkner's pro-active management model underlined the importance of media communication strategy. The role of media has been confirmed also in the SARS outbreak case in Toronto, where the information could even undermine the fragile economic situation. It is the most sensitive case how governments approach the situation and especially how media objectively report on the crisis. Marra [45] and Ritchie [9] noted "that poor communication strategies can often make the crisis worse". Public perception during crises and disasters is crucial, and Heath stated that "crises management is as much about dealing with human perception about the crisis and the management of crisis as it is about physically resolving the crisis situation" [4]. For example, despite the devastating outcome of Izmit earthquake in Turkey in 1999, a positive lesson learned from this disaster was a strong coordinative campaign and effective communication and public relation campaign that helped to overcome the catastrophic damages.

\section{Conclusions and implications}

In conclusion, it is important to mention that some authors were concerned with the applicability of models and the question was not how models should be constructed, but who will bear responsibilities and how models will operate in real settings.

The authors critically approached the fact that existence of pro-active risk management models is a golden rule to solve managerial decisions. As Wall indicated "it is important to consider who should bear the risk - and the answer will vary from place to place and with the nature of the risks" [38]. Every situation and environment is different and the authors in their articles mentioned even different settings of applicability of models, for example Faulkner discussed in his article about the responsibilities of communities to act during critical situations (in this case in tourism setting) [3]. Paraskevas and Arrendell by developing discussion on terrorist events as crises in tourism setting, underlined the role of DMOs in implementation of risk management models [6].

However, those discussions revealed interesting facts and questions that before the implementation of models such problems, as sufficient authority of entities, little control, creation of financial resources, co-operation among stakeholders, role of government in external situations, lack of proper jurisdiction, etc. have to be resolved. Moreover, some authors; for instance Faulkner did not mention specifically the responsibilities of particular members in community, which are critical for the successful application of models in real settings [3]. Ritchie stated "the type of crisis and disaster and its magnitude will impact upon 
stakeholders in different ways" [9]. In other words, different reactions and settings will be required in the case of an air strike (with the impact on tourist and other travelers) and the large-scale disasters and crises with more devastating impacts, not only on tourism.

For this reason, it is complicated to create generic models; on the other hand, it is worthwhile to attempt to do so and to protect other entities in an affected region from the collateral damage. The generic models have been applied in typical western countries as Great Britain and Australia, but some authors expressed their hesitation of applicability of generic models in the non-western environment and eastern cultures.

The attempts to devise universal model for tourism destinations was based on life-long academic expertise of scholars and their studies. For example, Faulkner implied extremely thorough approach through explaining the definitions and former research [3]. However, even the most logical and conceptual approach could create impediments in implementation. For instance, the generic model could not be fully implemented in all environments as formally intended. One of the reason, as Hofstede indicated, was "that people from different national cultures tend to have different styles of management" [36].
Many studied articles, discussing the risk management strategies, were finished before the situation has become even more emerging, but some articles appeared in academic journals especially in the last decade and revealed a necessity to pay more attention to this problem. The authors were preoccupied with the idea of creation of the generic pro-active models, which will be useful for detrimental situations. In some case, models were simulated during the disastrous situations and revealed that human society is rather complicated.

An important fact is that creation of models shifted human's curiosity ahead and raised a necessity of further research dealing not only with the applicability of models, but reactions and attitudes of stakeholders, community, government. Body of studied literature and its review enabled to explore constraints in implementation of models or risk management, as for example complexity of human society and its multicultural character, discuss the role of mass media and public relations in the recovery process, and define the differences among crises and disasters. For tourism and its performance and competitiveness, the risk management discourse needs to be taken into consideration because tourism activities and performance are dependent on the safe and secure environment and positive image is crucial for destinations.

\section{References}

[1] VANHOVE, N. A comparative analysis of competition models for tourism destinations. In: Progress in Tourism marketing. KOZAK, M., ANDREU, L. (eds). Oxford, UK: Elsevier, 2006, p. 101-114. ISBN 0080450407.

[2] CROUCH, J., RITCHIE, B. The competitive destination - a sustainable tourism perspective. Wallingford, UK: Cabi, 2003. ISBN 9780519966646.

[3] FAULKNER, B. Towards a framework for tourism disaster management. Tourism management [online]. 2001, 22(2), p.135-147. ISSN 0261-5177, eISSN 1879-3193. Available from: https://doi.org/10.1016/S0261-5177(00)00048-0

[4] HEATH, R. The Kobe earthquake: some realities of strategic management of crises and disasters. Disaster Prevention and Management [online]. 1998, 4(5), p. 11-24. ISSN 0965-3562, eISSN 1758-6100. Available from: https://doi.org/10.1108/09653569510100965

[5] MILlER, G. A., RITCHIE, B. W. A farming crisis or a tourism disaster? An analysis of the foot and mouth disease in the UK. Current Issues in Tourism [online]. 2003, 6(2), p. 150-171. ISSN 1368-3500, eISSN 1747-7603. Available from: https://doi.org/10.1080/13683500308667949

[6] PARASKEVAS, A., ARENDELL, B. A strategic framework for terrorism prevention and mitigation in tourism destinations. Tourism management [online]. 2007, 28(6), p. 1560-1573. ISSN 0261-5177, eISSN 1879-3193. Available from: https://doi.org/10.1016/j.tourman.2007.02.012

[7] FAULKNER, B., VIKULOV, S. Katherine, washed out one day, back on track the next: a post- mortem of a tourism disaster. Tourism management [online]. 2001, 22(4), p. 331-344. ISSN 0261-5177, eISSN 1879-3193. Available from: https://doi.org/10.1016/S0261-5177(00)00069-8

[8] SONMEZ, S. F., APOSTOLOPOUlOS, Y., TARLOW, P. Tourism in crisis: managing the effects of terrorism. Journal of Travel Research [online]. 1999, 38(1), p. 13-18. ISSN 0047-2875, eISSN 1552-6763. Available from: https://doi.org/10.1177/004728759903800104

[9] RITCHIE, B. W. Chaos, crises and disasters: a strategic approach to crisis management in the tourism industry. Tourism management [online]. 2004, 25, p. 669-683. ISSN 0261-5177, eISSN 1879-3193. Available from: https://doi.org/10.1016/j.tourman.2003.09.004

[10] SAUNDERS, M., LEWIS, P., THORNHILL, A. Research methods for business students. 3. ed. Harlow: Prentice-Hall, 2003. ISBN 978-0-273-71686-0.

[11] ECHTNER, C. M., JAMAL, T. B. The disciplinary dilemma of tourism studies. Annals of Tourism Research [online]. 1997, 24(4), p. 868-883. ISSN 0160-7383. Available from: https://doi.org/10.1016/S0160-7383(97)00060-1 
[12] PRIDEAUX, B., LAWS, E., FAULKNER, B. Events in Indonesia: exploring the limits to formal tourism trends forecasting methods in complex crisis situations. Tourism Management [online]. 2003, 24(4), p. 475-487. ISSN 0261-5177, eISSN 1879-3193. Available from: https://doi.org/10.1016/S0261-5177(02)00115-2

[13] LITVIN, S. W., ALDERSON, L. L. How Charleston got her groove back: a convention and visitors Bureau's response to 9/11. Journal of Vacation Marketing [online]. 2003, 9(2), p. 188-197. ISSN 1356-7667. Available from: https://doi.org/10.1177/135676670300900207

[14] FRISBY, E. Communication in a crisis: the British Tourist Authority's responses to the foot-and-mouth outbreak and 11th September. Journal of Vacation Marketing [online]. 2003, 9(1), p. 89-100. ISSN 1356-7667. Available from: https://doi.org/10.1177/135676670200900107

[15] FALL, I. The increasing role of public relations as a crisis management function: Empirical examination of communication re-strategizing efforts among destination organization managers in the wake of 11th September, 2001. Journal of Vacation Marketing [online]. 2004, 10(3), p. 238- 251. ISSN 1356-7667. Available from: https://doi.org/10.1177/135676670401000304

[16] YEOMAN, I., LENNON, J., BLACK, L. Foot-and-mouth disease: a scenario recurrence for Scotland's tourism industry. Journal of Vacation Marketing [online]. 2005, 11(2), p. 179-190. ISSN 1356-7667. Available from: https://doi.org/10.1177/1356766705052574

[17] DE SAUSMEREZ, N. Book review: restoring tourism destinations in crisis. Journal of Vacation Marketing [online]. 2005, 11(1), p. 103-104. ISSN 1356-7667. Available from: https://doi.org/10.1177/1356766705050849

[18] BARTON, L. Crisis management: preparing for and managing disasters. The Cormell Hotel and Restaurant Administration Quarterly [online]. 1994, 35(2), p. 59-65. ISSN 1938-9655, eISSN 1938-9663. Available from: https://doi.org/10.1177/001088049403500219

[19] DUROCHER, J. Recovery marketing: what to do after a natural disaster. The Cornell Hotel and Restaurant Administration Quarterly [online]. 1994, 35(2), p. 66-71. ISSN 1938-9655, eISSN 1938-9663. Available from: https://doi.org/10.1177/001088049403500220

[20] BEIRMAN, D. Marketing of tourism destinations during a prolonged crisis: Israel and the Middle East. Journal of Vacation Marketing [online]. 2002, 8(2), p. 167-176. ISSN 1356-7667. Available from: https://doi.org/10.1177/135676670200800206

[21] HENDERSON, J. C. Managing the Asian financial crisis: tourist attractions in Singapore. Journal of Travel Research [online]. 1999, 38(2), p. 177-181. ISSN 0047-2875, eISSN 1552-6763. Available from: https://doi.org/10.1177/004728759903800212

[22] MILO, K. J., YODER, S. L. Recovery from natural disaster: travel writers and tourist destinations. Journal of Travel Research [online]. 1991, 30(1), p. 36-39. ISSN 0047-2875, eISSN 1552-6763. Available from: https://doi.org/10.1177/004728759103000107

[23] PIZAM, A., FLEISCHER, A. Severity versus frequency of acts of terrorism: which has a larger impact on tourism demand? Journal of Travel Research [online]. 2002, 40(3), p. 337-339. ISSN 0047-2875, eISSN 1552-6763. Available from: https://doi.org/10.1177/0047287502040003011

[24] DRABEK, T. E. Disaster planning and response by tourist business executives. The Cornell Hotel and Restaurant Administration Quarterly [online]. 1995, Vol. 34, p. 81, 36(3), 86-96, 1995. ISSN 1938-9655, eISSN 1938-9663. Available from: https://doi.org/10.1016/0010-8804(95)96941-9

[25] MANSFELD, Y. Cycles of war, terror, and peace: determinants and management of crisis and recovery of the Israeli tourism industry. Journal of Travel Research [online]. 1999, 38(1), p. 30-36. ISSN 0047-2875, eISSN 1552-6763. Available from: https://doi.org/10.1177/004728759903800107

[26] GOODRICH, J. N. Book review: restoring tourism destinations in crisis: a strategic marketing approach. Tourism Management. 2005, 26(3), p. 475-476. ISSN 0261-5177, eISSN 1879-3193.

[27] PIZAM, A. A comprehensive approach to classifying acts of crises and violence of tourism destinations. Journal of Travel Research [online]. 1999, 38(1), p. 5-12. ISSN 0047-2875, eISSN 1552-6763. Available from: https://doi.org/10.1177/004728759903800103

[28] OKUMUS, F., KARAMUSTAFA, K. Impact of and economic crisis: evidence from Turkey. Annals of Tourism Research [online]. 2005, 32(4), p. 942-961. ISSN 0160-7383. Available from: https://doi.org/10.1016/j.annals.2005.04.001

[29] VAR, T., BRAYLEY, R., KORSAY, M. Tourism and world peace: case of Turkey. Annals of Tourism Research [online]. 1989, 16(2), p. 282-286. ISSN 0160-7383. Available from: https://doi.org/10.1016/0160-7383(89)90078-9

[30] QUINTAL, V. A., LEE, J. A., SOUTAR, G. N. Risk, uncertainty and the theory of planned behavior: a tourism example. Tourism Management [online]. 2010, 31(6), p. 797-805. ISSN 0261-5177, eISSN 1879-3193. Available from: https://doi.org/10.1016/j.tourman.2009.08.006

[31] PAUCHANT, T. C., MITTROFF, I. I. Transforming the crisis prone organization: preventing individual, organizational and environmental tragedies. San Francisco: Jossey-Bass, 1992. ISBN 978-1555424077. In: PARASKEVAS, A., ARENDELL, B. A strategic framework for terrorism prevention and mitigation in tourism destinations. Tourism Management [online]. 2007, 28, p. 1560-1573. ISSN 0261-5177, eISSN 1879-3193. Available from: https://doi.org/10.1016/j.tourman.2007.02.012 
[32] CAMPIRANON, K., SCOTT, N. Factors influencing crisis management in tourism destinations. In: Crisis management in tourism [online]. LAWS, E., PRIDEAUX, B., CHON, K. (eds). Wallingford, UK: Cabi Publishing, 2007, p. 142-156. ISBN 978-1-84593-047-9. Available from: https://doi.org/10.1079/9781845930479.0142

[33] TARLOW, P. Tourism Risk. e-Review of Tourism Research (eRTR). 2004, 2(3), p. 11-13. ISSN 1941-5842.

[34] TARLOW, P. Terrorism and Tourism. e-Review of Tourism Research (eRTR). 2005, 3(5), p. 18-21. ISSN $1941-5842$.

[35] HALL, C. M. Tourism and politics: policy, power and place. Chicshester, New York: Wiley \& Sons, 1994. ISBN 0471949191.

[36] HOFSTEDE, G. Culture's consequences: comparing values, behaviors, institutions, and organizations across nations. 2. ed. Thousand Oaks, CA: Sage, 2001. ISBN 0-8039-7323-3.

[37] MANSFELD, Y. Tourism, security and safety: from theory to practice. MANSFELD, Y., PIZAM, A. (eds.). Burlington, Mass.: Elsevier Butterworth-Heinemann, 2006. ISBN 9780750678988.

[38] WALL, G. Recovering from SARS: the case of Toronto tourism. In: Tourism, security and safety: from theory to practice. MANSFELD, Y., PIZAM, A. (eds.). Burlington, Mass.: Elsevier Butterworth-Heinemann, 2006. ISBN 9780750678988.

[39] SELBST, P. 1978. In: Crisis management strategy: competition and change in modern enterprises. BOOTH, S. New York: Routledge, 1993. ISBN 9781138183735. In: FAULKNER, B. Towards a framework for tourism disaster management. Tourism Management [online]. 2001, 22(2), p. 135-147. ISSN 0261-5177, eISSN 1879-3193. Available from: https://doi.org/10.1016/S0261-5177(00)00048-0

[40] COOMBS, T. Ongoing crisis communications: planning, managing and responding. Thousand Oaks, CA: Sage, 1999. ISBN 0761913203. In: RITCHIE, B., W. Chaos, crises and disasters: a strategic approach to crisis management in tourism industry. Tourism Management [online]. 2003, 25, p. 669-683. ISSN 0261-5177, eISSN 1879-3193. Available from: https://doi.org/10.1016/j.tourman.2003.09.004

[41] Crisis guidelines for the tourism industry - World Tourism Organization [online]. Available from: https://www.e-unwto.org In: CAMPIRANON, K., SCOTT, N. Factors influencing crisis management in tourism destinations. In: Crisis management in tourism [online]. LAWS, E., PRIDEAUX, B., CHON, K. (eds). Wallingford, UK: Cabi Publishing, 2007, p. 142-156. ISBN 978-1-84593-047-9. Available from: https://doi.org/10.1079/9781845930479.0142

[42] Pacific Asia Travel Association [online]. Available from: https://www.pata.org In: CAMPIRANON, K., SCOTT, N. Factors influencing crisis management in tourism destinations. In: Crisis management in tourism [online]. LAWS, E., PRIDEAUX, B., CHON, K. (eds). Wallingford, UK: Cabi Publishing, 2007, p. 142-156. ISBN 978-1-84593-047-9. Available from: https://doi.org/10.1079/9781845930479.0142

[43] FANN, P., ZIGANG, Z. In: CAMPIRANON, K., SCOTT, N. Factors influencing crisis management in tourism destinations. In: Crisis management in tourism [online]. LAWS, E., PRIDEAUX, B., CHON, K. (eds). Wallingford, UK: Cabi Publishing, 2007, p. 142-156. ISBN 978-1-84593-047-9. Available from: https://doi.org/10.1079/9781845930479.0142

[44] JOHNSON, V., PEPPAS, S. Crisis management in Belgium: the case of Coca-Cola. Corporate Communications: An International Journal [online]. 2003, 8(1), p. 18-22. ISSN 1356-3289. Available from: https://doi.org/10.1108/13563280310458885 In: CAMPIRANON, K., SCOTT, N. Factors influencing crisis management in tourism destinations. In: Crisis management in tourism [online]. LAWS, E., PRIDEAUX, B., CHON, K. (eds). Wallingford, UK: Cabi Publishing, 2007, p. 142-156. ISBN 978-1-84593-047-9. Available from: https://doi.org/10.1079/9781845930479.0142

[45] MARRA, F. Crisis communication plans: Poor prediction of excellent crisis public relations. Public Relations Review. 1998, 24(4), p. 461-474. ISSN 0363-8111. In: RITCHIE, B. W. Chaos, crises and disasters: a strategic approach to crisis management in the tourism industry. Tourism management [online]. 2004, 25, p. 669-683. ISSN 0261-5177, eISSN 1879-3193. Available from: https://doi.org/10.1016/j.tourman.2003.09.004 